\title{
Totally extraperitoneal inguinal hernia repair versus Lichtenstein repair: a one-year follow-up study
}

\author{
H. O. Havrylov ${ }^{1}$, O. V. Shulyarenko ${ }^{2}$ \\ ${ }^{1}$ Clinic Medikom, Kyiv \\ ${ }^{2}$ Bogomolets National Medical University, Kyiv
}

$\bigotimes$ Oleg Shulyarenko: oleg.v.shu@gmail.com

H.O. Havrylov, http://orcid.org/0000-0002-8425-8134

O.V. Shulyarenko, http://orcid.org/0000-0002-6780-8587

The inguinal hernia has an incidence of $27-43 \%$ in males. Surgical repair is the most accepted treatment to prevent the development of complications. Laparoscopic inguinal hernia repair has become popular worldwide and includes the use of a laparoscopic technique for mesh placement behind the defect.

Овјестіve - to assess whether totally extraperitoneal (TEP) inguinal hernia repair shows benefits over Lichtenstein repair in intraoperative and one-year follow-up postoperative outcomes for male patients with primary unilateral inguinal hernia.

Materials AND MeTHODS. 53 males were randomly allocated to two groups. Group 1 included 27 patients who underwent totally extraperitoneal hernia repair using self-gripping lightweight mesh, and group 2 included 26 patients who were treated surgically with Lichtenstein repair using lightweight mesh.

Results. Both groups were comparable in mean age, type of hernia, body mass index and patient's distribution according to the European hernia society classification. TEP repair takes on average a little less time as compared to Lichtenstein repair, and this difference is not statistically significant. The mean of visual analogue scale for pain scoring in the first 24 hours after surgery as well as in the next 24 hours is statistically significantly smaller in group 1 compared to group 2. The mean time taken to return to work was 2.15 times longer in group 2 than in group 1, and the difference was statistically significant.

Conclusions. Totally extraperitoneal hernia repair shows potential benefits over Lichtenstein repair for primary unilateral inguinal hernias as it causes less pain in the postoperative period and ensures early return to work.

\section{KEYwORDS}

totally extraperitoneal hernia repair, Lichtenstein repair, inguinal hernia, surgery.

ARTICLE • Received 2021-10-18 • Received in revised form 2021-11-01

(C) General Surgery, 2021

The inguinal hernia has an incidence of $27-43 \%$ in males. Surgical repair is the most accepted treatment to prevent the development of complications $[6,12,13]$. Mesh repair is generally preferred in inguinal hernia surgery. Open non-tension mesh hernioplasty has been the «gold standard» in inguinal hernia surgery for a long time [1]. At first, the laparoscopic inguinal hernia repair (LIHR) was introduced by R. Ger et al. in 1990 [5]. LIHR has become popular worldwide because laparoscopic placement of mesh behind the defect where, according to Laplace's Law, the same forces that cause hernia are used to reinforce the repair [4]. The totally extraperitoneal method (TEP) established by J. L. Dulucq in
Europe allows access to the pre-peritoneal space and avoids the need for a peritoneal incision [3].

Овјестіve - to assess whether totally extraperitoneal inguinal hernia repair shows benefits over Lichtenstein repair in intraoperative and one-year follow up postoperative outcomes for male patients with primary unilateral inguinal hernia.

\section{Materials and methods}

53 males with primary unilateral inguinal hernia were enrolled in the study and operated in the clinic «Medikom» from 2016 to 2019 years. Patients over 18 years of age with primary unilateral 
evident uncomplicated inguinal hernia who fit for both laparoscopic and open approach were included in the study. All of them were randomly allocated to two groups: group 1 included 27 patients who underwent totally extraperitoneal inguinal hernia repair by our method (patent of Ukraine No 102998) using electric bipolar welding hemostasis and selfgripping lightweight mesh with polypropylene fibers and polylactic acid micro hooks, and group 2 included 26 patients who were treated surgically with Lichtenstein repair [10] using electric bipolar welding hemostasis and lightweight mesh. Preoperative evaluation was based on proper analysis of the medical history, full clinical examination, laboratory investigations and ultrasound of the abdominal cavity, pelvis and inguinal area. Early postoperative therapy included pain relievers, correction of cardiovascular and respiratory disorders, antibacterial and anticoagulation therapy. Table shows patient demographics and patient distribution in both groups according to the European hernia society (EHS) inguinal hernia classification [11].

The following parameters were evaluated: operating time, pain severity within the first 24 hours and within the next 24 hours after surgery (using 10-balls VAS score), postoperative complications over a 12-month follow-up period, mean time taken to return to work.

The statistical software package was used in this study. The independent ' $t$ ' test was used to compare age, operating time, severity of postoperative pain, mean time taken to return to work. Quantitative data are presented as mean and average deviation from the mean $(\mathrm{M} \pm \mathrm{m}) . \mathrm{p}<0.05$ was considered statistically significant. Patient distribution based on EHS-classification and on direct/indirect inguinal hernia type were were analysed by Chi-square test $\left(\chi^{2}\right) . p<0.05$ was considered statistically significant.

\section{Results and discussion}

Table shows that the difference in mean age, type of hernia, body mass index and patient distribution according to the EHS classification was not statistically significant between the two groups. Therefore, both groups were comparable.

Indirect hernia appeared to be the most common type of hernia in both groups.

The operating time in minutes was $36.78 \pm 0.61$ in group 1 and $37.08 \pm 0.82$ in group $2(\mathrm{p}>0.05)$. The difference is not statistically significant. It means that the TEP repair takes on average a little less time as compared to Lichtenstein repair.

In group 2 both inguinal nerves were recognized in $14(53.85 \%)$ patients, the ilioinguinal nerve in
Table. Patient demographics and patient distribution in both groups according to the European hernia society inguinal hernia classification

\begin{tabular}{lcc}
\hline Variable & Group 1 & Group 2 \\
\hline Age, years & $\begin{array}{c}39.7 \pm 2.08 \\
(19-60)\end{array}$ & $\begin{array}{c}38.62 \pm 2.33 \\
(18-61)\end{array}$ \\
\hline $\begin{array}{l}\text { Inguinal hernia type } \\
\text { direct/indirect }\end{array}$ & $5 / 22$ & $4 / 22$ \\
\hline
\end{tabular}

Body mass index, $\mathrm{kg} / \mathrm{m}^{2}$

$24.15 \pm 0.35 \quad 23.96 \pm 0.38$

European hernia society inguinal hernia classification

\begin{tabular}{ccc}
\hline PM1 & 1 & 1 \\
\hline PM2 & 3 & 2 \\
\hline PM3 & 1 & 1 \\
\hline PL1 & 4 & 5 \\
\hline PL2 & 12 & 10 \\
\hline PL3 & 6 & 7 \\
\hline
\end{tabular}

All $\mathrm{p}>0.05$.

Quantitative data are presented as mean and average deviation $(\mathrm{M} \pm \mathrm{m})$.

The data range is given in brackets.

$4(15.38 \%)$ patients, the iliohypogastric nerve in $3(11.54 \%)$ patients, and no nerves in $5(19.23 \%)$ patients.

The pain score during the first 24 hours after surgery was $2.41 \pm 0.11$ balls in group 1 comparing to $3.04 \pm 0.17$ in group $2(p<0.05)$. It suggests that the difference in pain score was significant, so we can conclude that within the first 24 hours patients in group 1 had a less pain score compared to group 2.

The pain score within the next 24 hours was $1.3 \pm 0.09(\mathrm{M} \pm \mathrm{m})$ balls in group 1 versus $1.88 \pm 0.09$ in group $2(\mathrm{p}<0.05)$. The difference is statistically significant. Thus, within the first 24 hours and within the next 24 hours, patients in the laparoscopic group experienced less pain than patients in the open surgery group.

In group 1, the postoperative complications were noted in $1(3.7 \%)$ patient who developed port site seroma. The seroma was punctured under ultrasound supervision.

In group 2, the postoperative complications occurred in $2(7.69 \%)$ patients. One of them developed surgical wound seroma, another one developed surgical wound hematoma. All these patients underwent puncture under ultrasound supervision, and the hematoma was coagulated. 
The mean time taken to return to work was $7.96 \pm 0.15(\mathrm{M} \pm \mathrm{m})$ days in group 1 and $17.08 \pm 0.17$ $(\mathrm{M} \pm \mathrm{m})$ days in group $2(\mathrm{p}<0.05)$.

No wound infection, chronic pain, or recurrence was found in both groups over a 12-month followup period.

Surgical equipment and surgical techniques are constantly evolving, so the surgeons can choose from the most popular ones. To quote $\mathrm{J}$. Bruce of Edinburgh: «The final word on hernia will probably never be written» [9]. The introduction of tensionfree repair using prosthetic mesh represented a new era in inguinal hernia repair [14]. Nonabsorbable mesh types such as polypropylene, polytetrafluorethylene, and polyester were initially used for hernia repair. Among these, heavy polypropylene mesh was most commonly used because it had many benefits such as being flexible, strong, easily cut, readily integrated by surrounding tissues, and resistant to the infection. However, postoperative pain and foreign body sensation constantly bothered patients, and thus lightweight and ultralightweight meshes were developed. However, although the use of the lightweight mesh resulted in much less postoperative pain and reduced foreign body sensation compared with the use of the heavyweight nonabsorbable mesh, decreased intraoperative control and increased recurrence rates were more common. To maximize both intraoperative control and postoperative comfort as well as minimize the recurrence rates, partially absorbable prostheses have been recently developed and are made up of nonabsorbable materials, such as polypropylene as a standard, and absorbable materials, such as polyglactin that allows leaving less foreign material in the recipient's body without compromising the mechanical resistance [15].

Preperitoneal mesh reinforces the internal inguinal ring, the Hesselbach's triangle and annulus femoralis, where the inguinal hernia sac develops. Therefore, preperitoneal repair is indicated for the treatment of indirect, direct and femoral hernias. The mesh was used in group 1. It is made up of monofilament polyester and a resorbable polylactic acid gripping system which perfects true tensionfree repair. The microhooks cover the entire upper side of the material and allow anchoring the mesh to the tissue. Therefore, a smaller suture is required, and there is less chance of nerve entrapment that can be a reason for postoperative pain. Thus, the use of such self-fixing mesh in laparoscopic surgery is safe and feasible and may reduce postoperative pain. Our study confirms the hypothesis that the fixation of the mesh with sutures in group 2 is a time-consuming procedure and accounts for the majority of the operating time. Consequently, open mesh repair is much more appropriate for all varieties of inguinal hernias such as sliding, irreducible, strangulated hernia as well as for patients with co-morbidity [2].

Seromas are known to be the most common postoperative complication after TEP inguinal hernia repair [15], and they also occurred most often in this study.

The mean of VAS for pain scoring within the first 24 hours after surgery as well as within the next 24 hours gives evidence of less severe acute pain in the laparoscopic repair group as compared to Lictenstein repair group and this difference is statistically significant. TEP repair produced less surgical trauma than open Lichtenstein hernia repair method. This result is similar to the results obtained in similar comparative studies done in the past [7, 8].

The mean time taken to return to work was 2.15 times longer in group 2 than in group 1. It also confirms the fact that TEP repair produced less surgical trauma than open Lictenstein hernia repair method.

There were no life-threatening complications, no recurrence of hernia over a 12-month median follow-up period in both groups. However, additional studies are necessary for further investigation of the previously observed recurrences.

The laparoscopic approach provides magnification of the surgical field for inspection of the entire myopectineal orifice well, allowing surgeons to repair any unexpected hernias simultaneously. Consequently, the recurrence rate can be reduced [3]. Our study noted the following benefits of laparoscopic surgery: less pain in the postoperative period, faster recovery and appropriate safety.

In this study, no mortalities were documented. In the literature, the mortality rate after an elective hernia repair doesn't exceed $0.2 \%$ and is related to the existing comorbidities [13].

\section{Conclusions}

Totally extraperitoneal hernia repair shows potential benefits over Lichtenstein repair for primary unilateral inguinal hernias as it ensures less pain in the postoperative period and early return to work. Continuous innovations and improved technologies will ultimately determine whether totally extraperitoneal hernia repair will become a generally accepted method in surgery.

\section{ACKNOWLEDGEMENTS}

The authors gratefully acknowledge the support of the Bogomolets National Medical University administration and the Clinic «Medikom» administration and its staff. 


\section{DEClARATION OF INTERESTS}

Authors declare that they have no conflicts of interest.

Funding. No grants or support were used in this study.

\section{ETHICS APPROVAL AND WRITTEN INFORMED CONSENTS STATEMENTS}

All procedures, performed in the study and involving human participants, were carried out in accordance with the ethical standards of the institutional and/or national research committee and with the 1964 Helsinki declaration and its later amendments or comparable ethical standards.

Written informed consent was obtained from all individual participants included in the study.

\section{AUTHOR CONTRIBUTIONS}

H. O. Havrylov: the implementation of the research; O. V. Shulyarenko: to the design of the research, the analysis of its results and manuscript writing.

\section{REFERENCES}

1. Anadol AZ, Akin M, Kurukahvecioglu O, et al. A prospective comparative study of the efficacy of conventional Lichtenstein versus self-adhesive mesh for inguinal hernia. Surg Today. 2011;41(11):1498-503. https://doi.org/10.1007/s00595-0114545-8.

2. Bowling K, El-Badawy S, Massri E, et al. Laparoscopic and open inguinal hernia repair: Patient reported outcomes in the elderly from a single centre-A prospective cohort study. Annal Med Surg 2017 Oct;22:12-5 https://doi.org/10.1016/j.amsu.2017.08.013

3. Dulucq JL, Wintringer P, Mahajna A. Laparoscopic totally extraperitoneal inguinal hernia repair: lessons learned from 3100 hernia repairs over 15 years. Surg Endosc 2009;23:482-6. https://doi org/10.1007/s00464-008-0118-3.

4. Feleshtynsky YaP, Shtaier A. An improved transabdominal preperitoneal alloplast for recurrent inguinal hernias after Lichtenstein's surgery. EUREKA: Health Sciences.; 4 (2020):77-81. doi: 10.21303/2504-5679.2020.001364

5. Ger R, Mishrick A, Hurwitz J, Romero C, Oddsen R. Management of groin hernias by laparoscopy. World J Surg. 1993;17(1):46-50 https://doi.org/10.1007/BF01655704.

6. Hachisuka T. Femoral hernia repair. Surg Clin N Am. 2003;83:1189-1205. https://doi.org/10.1016/S00396109(03)00120-8
7. Ielpo B, Duran H, Diaz E, et al. A prospective randomized study comparing laparoscopic transabdominal preperitoneal (TAPP) versus Lichtenstein repair for bilateral inguinal hernias. Am J Surg. 2017 Jul 19: S0002-9610(17)30662-1. https://doi.org/10.1016/j. amjsurg.2017.07.016.

8. Kozol R, Lange PM, Kosir M, et al. A prospective, randomized study of open vs laparoscopic inguinal hernia repair. An assessment of postoperative pain. Arch Surg. 1997;132(3):292-5 https://doi.org/10.1001/archsurg.1997.01430270078015

9. Legutko J, Pach R, Solecki R, et al. The history of treatment of groin hernia. Folia Med Cracov. 2008;49:57-74.

10. Lichtenstein IL, Shulman AG, Amid PK. Twenty questions about hernioplasty. The American surgeon. 1991;57(11):730-3

11. Miserez M, Alexandre JH, Campanelli G, et al. The European hernia society groin hernia classification: simple and easy to remember Hernia. 2007;11:113. https://doi.org/10.1007/s10029007-0198-3.

12. Nichitailo ME, Bulik II. Sovremennye aspekty endovideokhirurgicheskogo lecheniia slozhnykh i retsidivnikh pakhovykh gryzh [Modern aspects endovideosurgical treatment of complex and recurrent inguinal hernias]. Klin Khirurgiia. 2010;(3):10-6. Russian.

13. Simons MP, Smietanski M, Bonjer HJ, et al. International guidelines for groin hernia management. Hernia Surge Group. Hernia. 2018;22:1-165. https://doi.org/10.1007/s10029-017-1668-x.

14. Usher FC. Hernia repair with knitted polypropylene mesh. Surg Gynecol Obstet. 1963;117:239-40.

15. Yang HW, Kang SH, Jung SY, Min BW, Lee SI. Efficacy and safety of a novel partially absorbable mesh in totally extraperitoneal hernia repair. Annals of surgical treatment and research. 2017;93(6):316-21. https://doi.org/10.4174/astr.2017.93.6.316.

\section{Порівняння тотальної екстраперитонеальної пластики пахової грижі та пластики за Ліхтенштейном: 1 рік спостереження}

\section{Г. О. Гаврилов ${ }^{1}$, О. В. Шуляренко ${ }^{2}$}

${ }^{1}$ Клініка «Медіком», Київ

${ }^{2}$ Національний медичний університет імені О. О. Богомольця, Київ

Пахова грижа виникає у чоловіків у 27-43\% випадків. Хірургічне втручання - найбільш прийнятний метод лікування, що дає змогу уникнути розвитку ускладнень. Лапароскопічна пластика пахової грижі набула популярності у світі завдяки лапароскопічному встановленню сітки за дефектом.

Мета - оцінити переваги тотальної екстраперитонеальної пластики пахових гриж порівняно з операцією Ліхтенштейна в інтраопераційний період і протягом 1 року після операції у пацієнтів чоловічої статі 3 первинною однобічною паховою грижею.

Матеріали та методи. Випадковим чином 53 пацієнти розділили на дві групи залежно від способу лікування: 1-ша (n=27) - тотальна екстраперитонеальна пластика з використанням полегшеної сітки, яка самофіксується, 2-га (n=26) - операція Ліхтенштейна з використанням полегшеної сітки. 
Результати. Обидві групи були однорідні за середнім віком, типом грижі, індексом маси тіла та розподілом пацієнтів за Європейською класифікацією герніологів. Тривалість виконання тотальної екстраперитонеальної пластики пахових гриж в середньому була статистично незначущо дещо меншою порівняно з операцією Ліхтенштейна. Середнє значення за візуальною аналоговою шкалою для оцінки болю протягом перших 24 год після операції, а також протягом наступних 24 год було статистично значущо менше в 1-й групі. Середня тривалість відновлення працездатності в 2-й групі була в 2,15 разу статистично значущо більшою, ніж у 1-й.

Висновки. Потенційні переваги тотальної екстраперитонеальної пластики порівняно з операцією Ліхтенштейна в хірургії первинних однобічних пахових гриж полягають у меншій інтенсивності післяопераційного болю і швидшому відновленні працездатності.

ключові слова: тотальна екстраперитонеальна пластика грижі, операція Ліхтенштейна, пахова грижа, хірургія.

\section{Автори}

$\bigotimes$ Шуляренко Олег Володимирович: oleg.v.shu@gmail.com

Г.О. Гаврилов, лікар-хірург, завідуючий хірургічним відділенням, http://orcid.org/0000-0002-8425-8134

О. В. Шуляренко, лікар-хірург, к. мед. н., асистент кафедри загальної хірургії № 2, http://orcid.org/0000-0002-6780-8587

\section{F O R C I T A T I O N}

I Havrylov HO, Shulyarenko OV. Totally extraperitoneal inguinal hernia repair versus Lichtenstein repair: a one-year follow-up study. General Surgery (Ukraine). 2021:1;31-35. http://doi. org/10.30978/GS-2021-1-31. 